\title{
A Scrap of Time (Skrawek czasu)
}

Author: Ida Fink

First Published: In Hebrew 1974 (originally written in Polish but not published until 1987).

Translations: Hebrew (Pisat zeman: sipurim, 1974; the new translation ha-Gan ha-maflig la-merhaḳim, 1988); German (Eine Spanne Zeit, 1983); Dutch (Een klein ogenblik, 1985); English (A Scrap of Time and Other Stories, 1987); French (Le jardin à la dérive, 1991), Italian (Frammenti di tempo, 1995); Russian (Uplyvajuščij sad , 2019) and others.

Film Adaptations: Le Jeu de la clé (The Key Game), directed by Michel Hassan; based on The Key Game. France, 1995.

About the Author: Ida Fink (1921-2011) was born as Ida Landau in Zbarazh, East Galicia (after the war USSR, now Ukraine) to a family of secular Jews that was integrated into Polish culture. In 1938 she started studying at the Lviv Conservatory, but the German invasion of USSR in 1941 interrupted her studies. Ida Landau was confined to the Zbarazh Ghetto with her family until 1942, when she and her younger sister Elsa acquired "Aryan papers" and travelled to Germany as Polish forced labourers. A fair haired, blue-eyed young Ida did not look identifiably Jewish, quite the opposite of her sister. They both survived. A fictionalised account of the war years appears in her novel The Journey (1990). Ida and Elsa spent almost a year in the Displaced Person Camp Ettlingen where she made her writing debut with an essay in the camp newspaper Nasz głos. In 1946, they came back to Poland and stayed in Silesia. In 1948 Ida married Bruno Fink, a survivor of four camps. In 1957, the whole family moved to Israel and settled in Holon. Ida Fink immediately started to publish her short stories in various Polish language periodicals in Israel and the UK. In the 1960s she worked for the Yad Vashem Institute as a testimony recorder, in the 1970s as a librarian in the music section of the Goethe Institute in Tel Aviv. Since the late 1980s, her prose has gained great popularity and won many important literary awards. All her life Fink wrote in Polish.

Further Important Publications: Podróż (1990, The Journey; autobiographical novel); Ślady (1996, Traces; short stories and three one-act dramas); Odpływający ogród (2001, The Floating Garden; collected works); Wiosna 1941 (2009, The Spring 1941; short stories).

\section{Content and Interpretation}

Ida Fink started to write her short stories in Polish shortly after the war. Her first story Doorstep (Próg) was published in 1948 written under the pseudonym Elza (the name of Ida Fink's sister) in the Swiss magazine Action. In the 1950s and 1960s, the author

Ә Open Access. () 2021 Barttomej Krupa, published by De Gruyter. (cc) BY-NC-ND This work is licensed under a Creative Commons Attribution-NonCommercial-NoDerivatives 4.0 License. https://doi.org/10.1515/9783110671056-088 
regularly published in Israeli Polish-language press, especially in weekly Od Nowa. In turn, the aforementioned collection of her short stories called A Scrap of Time appeared for the first time in 1974 having been translated into Hebrew. The original Polish émigré edition of the London Annex from 1987 was just one of several publications (after the German edition of 1983 and the Dutch edition of 1985) of this collection. In the same time (1988) three samizdat editions were published in Poland. The second Polish edition was published in 1992 in London. All of the short stories from this collection later became part of the main, almost complete Polish edition The Floating Garden. Gathered Stories (2002). It contains 28 short stories. In the writer's archive in the National Library of Israel in Jerusalem, a list of projects with numerous strikethroughs and changes can be seen, which proves that the stories in the collection are fully consciously arranged.

The first short story The End (Koniec) repaints the tension between two characters who are only referred to as She and He. They are both standing on the balcony in a quite big city (Lviv). He wants tenderness from her, but she rejects this in the premonition of a catastrophe. They recall a happy past while the war is starting right in front of their eyes. The most important and powerful story, A Scrap of Time, combines veristic details of the first action in Zbarazh and the death of Fink's cousin David with reflection over receiving various time planes and languages - before and after the annihilation. One of the main inspirations is probably Proust's In Search of Lost Time. As Ewelina Kotarska wrote: "The concept of time in Ida Fink's works [...] bears traces of three temporal perspectives: the past, the presence, and the future, and therefore result in being temporal hybrids" (Kotarska, 2010, p. 304).

One of the most well-known and widely used works in high school and academic education in Israel, Poland and the United States is the story The Key Game. The use of the work at the Polish maturity exam (the equivalent of the British A-levels) in 2005 was symbolic. It is a story of Ida Fink's husband and his lost family - his first wife and son. Both parents are teaching their three-year-old blue-eyed son a game in order to take as long as possible to unlock and open the door at the moment the Germans come. They call it "the key game", because the son has to pretend that he is looking for the key to the door. The extra time is needed for the "bad-looking" father to hide in the bathroom.

Most of the stories talk about Ida Fink's own experiences (The Floating Garden), her family (esp. her father, e.g. in the story The Pig), people she knew and who were killed (Death of Tsarina) or her friends (Jump!). Polish-Jewish relations are shown clearly and with incredible irony-lined force in The Shelter. After the war, Jews are visiting a Polish family who had hidden them in their home during the time of the occupation. The Polish family shows the Jews the new house they had built after the war from money which the Jews had given them to hide them. The new house also contains a new shelter: 
"What are we supposed to make of that?" asked the man. "Sentenced to a hiding-place, sentenced to death once again? And by whom? By good people who wish us well. It's appalling. To build a hiding-place out of the goodness of one's heart! That's what's so horrible.” (Fink, 1995, p. 34)

The stories Splinter and especially The Tenth Man are about the direct consequences of the Holocaust. After the war, the Jews slowly return to the town from their hiding places. They look for their loved ones and they want to say the Kaddish prayer but they are unable to achieve a minyan - which means the presence of ten male adults.

\section{Main Topics and Problems}

One of the most important subjects of Fink's short stories is the individual experience and psychic effects of the Shoah. First of all, Fink evokes a sense of isolation and abandonment. She writes about this in most of her stories from this collection, which is crucial if one treats her work as a testimony. As one of her early critics stressed: "the author emphasises the autobiographical nature of her work. A Scrap of Time is a collection of stories based almost exclusively on her own experience and the experience of her loved ones and friends. There are no fictitious events and characters" (Gorczyński, 1987, p. 465). The action of most of her stories is situated in a small town in which we recognise as Zbarazh. On the other hand, the writer abbreviates topographical names, i.e. Zbarazh is called "city Z.", which gives the stories a more universal character. But generally Ida Fink presents the image of the Shoah as if from below. She avoids any generalisations, since her gaze is attached to details. A very important metaphor of her writing is the trace (see Krupa, 2016). Other important figures are nature (river, spring, time of day, e.g. morning) and animals who are more human than the humans. The animals can be found in various stories and take on the role of protecting the Jews (Krupa, 2017). Very often her heroes and narrators present the female experiences of the Holocaust. Sometimes their experience is completely unique and touches specific traumas. For example, the story Aryan Papers talks about sexual violence (see Calderón Puerta, 2015). A Polish man demands sex from a young Jewish girl in return for false documents.

What is visible at a glance is the very specific, individual, immediately recognizable language of Fink's prose. She combines the full tension and dramatic events of the Shoah with clear and compact sentences. Her stories are short and very often end with an expressive punch line. Critics often characterised it as a "silent scream". Her method can be called minimalism or "impeccable economy of words" (Sillitoe, 1989). In one of the interviews she said: "I write about experiences taking place not only in the geographical landscape, but also in spiritual and linguistic" (Szewc, 2003, p. 5). In her personal copy of the book there are numerous modifications, deleted words and changes. They testify to the fact that the writer continuously, up until her death, worked on her literary prose and they are also a testimony to her incredible verbal care. 


\section{Cited Works}

Calderón Puerta, A. (2015). Motyw gwałtu w opowiadaniach Aryjskie papiery Idy Fink i w dramacie Nasza klasa Tadeusza Słobodzianka. Teksty Drugie, 26(2), pp. 203-214. Fink, I. (1995). Jean Christophe. In: I. Fink, A Scrap of Time and Other Stories. Evanston, ILL: Northwestern University Press, pp. 31-35.

Gorczyński, R. (1987). [Review]. The Polish Review (N.Y.), 32(4), pp. 464-467. Kotarska, E. (2010). Doświadczanie czasu w twórczości Idy Fink. Acta Universitatis Lodziensis. Folia Litteraria Polonica, (13), pp. 281-304. Krupa, B. (2016). Traces of the Holocaust Immanent Category of Ida Fink's Prose. In: B. Sienkiewicz, S. Karolak, eds., Ślady II wojny światowej i Zagłady w najnowszej literaturze polskiej. Poznań: Wydawnictwo Nauka i Innowacje, pp. 165-186. Krupa, B. (2017). Human-Dog Relation in Ida Fink's Short Stories. Narracje o Zagładzie, (3), pp. 139-160. Sillitoe, A. (1989). Foreword. In: I. Fink, A Scrap of Time and Other Stories. New York: Penguin, without pages. Szewc, P. (2003). Ocalić pamięć. Nowe Książki, (5), pp. 4-5.

\section{Further References}

Famulska, K. (2010). Polacy, Żydzi, Izraelczycy. Tożsamość w literaturze polskiej w Izraelu. Toruń: Wydawnictwo UMK, Archiwum Emigracji 30. Fink, I. (2003). Ocalić pamięć. Z I. Fink rozmawia P. Szewc. Nowe Książki, (5), pp. 4-5. Horowitz, S. R. (1997). Voicing the Void: Muteness and Memory in Holocaust Fiction. Albany: State University of New York Press. Kremer, L. S. (1999). Women's Holocaust Writing: Memory and Imagination, Lincoln: University of Nebraska Press. Milner, I. (2008). Towards a New Reading of Fink's The Journey. In: L. O. Vasvári, S. T. de Zepetnek, eds., Comparative Central European Holocaust Studies. West Lafayette: Purdue UP, pp. 147-157. Ofer, D., Weitzman L. J., eds. (1998). Women in the Holocaust. New Haven and London: Yale University Press. Ramras-Rauch, G. (1999). Ida Fink and Holocaust Literature. In: J. T. Borrás, A. Sáenz Badillos, eds., Jewish Studies at the Turn of the Twentieth Century: Proceedings of 6th EAJS Congress. London, Boston, Köln: Brill, pp. 225-228. Rzadca, A. (2012). Foto-Grafie. Fotografische Narrativität im Werk von Ida Fink. Foto-bio-grafisches Erzählen in der polnischen Literatur. München: Akademische Verlagsgemeinschaft München. Śliwiński, P. (2003). Przeszły nieprzedawniony. Tygodnik Powszechny, (12), p. 11. Wilczyński, M. (1994), Trusting the Words: Paradoxes of Ida Fink. Modern Language Studies, 24(4), pp. 25-38.

BK 